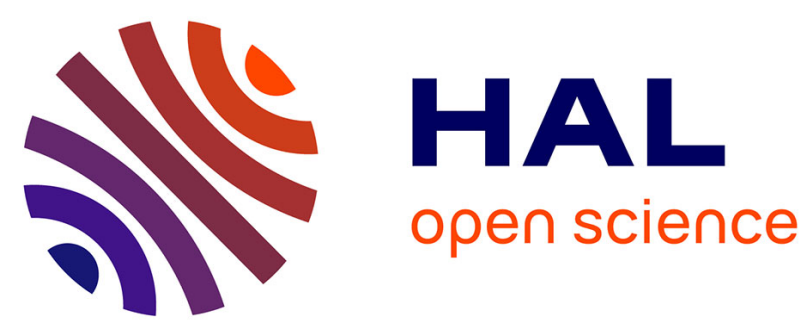

\title{
Enzymatic Iron Oxidation and Reduction in Magnetite Synthesizing Magnetospirillum Magnetotacticum
}

\author{
Y. Fukumori, H. Oyanagi, K. Yoshimatsu, Y. Noguchi, Taiga Fujiwara
}

\section{To cite this version:}

Y. Fukumori, H. Oyanagi, K. Yoshimatsu, Y. Noguchi, Taiga Fujiwara. Enzymatic Iron Oxidation and Reduction in Magnetite Synthesizing Magnetospirillum Magnetotacticum. Journal de Physique IV Proceedings, 1997, 07 (C1), pp.C1-659-C1-662. 10.1051/jp4:19971270 jpa-00254982

\section{HAL Id: jpa-00254982 https://hal.science/jpa-00254982}

Submitted on 1 Jan 1997

HAL is a multi-disciplinary open access archive for the deposit and dissemination of scientific research documents, whether they are published or not. The documents may come from teaching and research institutions in France or abroad, or from public or private research centers.
L'archive ouverte pluridisciplinaire HAL, est destinée au dépôt et à la diffusion de documents scientifiques de niveau recherche, publiés ou non, émanant des établissements d'enseignement et de recherche français ou étrangers, des laboratoires publics ou privés. 


\title{
Enzymatic Iron Oxidation and Reduction in Magnetite Synthesizing Magnetospirillum Magnetotacticum
}

\author{
Y. Fukumori, H. Oyanagi, K. Yoshimatsu, Y. Noguchi and T. Fujiwara
}

Department of Life Science, Faculty of Bioscience and Biotechnology, Tokyo Institute of Technology, 4259 Nagatsuta, Midori-ku, Yokohama 226, Japan

\begin{abstract}
We investigated the enzymatic reduction and oxidation of iron in M.magnetotacticum which synthesizes magnetite at room temperature. $\mathrm{NADH}-\mathrm{Fe}(\mathrm{III})$ reductase with the molecular mass of $36 \mathrm{kDa}$ was purified from the bacterium. The enzyme was located in cytoplasm and utilized NADH and NADPH in the presence of FMN as reductant and showed maximum activity at $\mathrm{pH} 7.0$. The $\mathrm{Km}$ for $\mathrm{NADH}$ and $\mathrm{NADPH}$ were about $4.3 \mu \mathrm{M}$ and $119 \mu \mathrm{M}$, respectively. The enzymatic activity was strongly inhibited by $\mathrm{Zn}^{2+}$. On the other hand, the dissimilatory nitrite reductase of M.magnetotacticum showed high $\mathrm{Fe}(\mathrm{II})$-nitrite oxidoreductase activity. The enzyme was located in periplasmic space and could be isolated from the magnetite-containing cells but not from the non-magnetic cells. The enzyme composed of two identical subunits with a molecular mass of $54 \mathrm{kDa}$, each containing a $c$ - and $d_{1}$-type heme. The activity was about $0.57 \mathrm{~mol}$ ferrous iron/mol of enzyme/sec at $\mathrm{pH}$ 8.0. The oxidized ferrous iron/reduced nitrite ratio was about 1.4, indicating that nitrite was reduced to NO. Furthermore, M.magnetotacticum synthesized much more magnetites when the bacterium grew using denitrification, the dissimilatory reduction of nitrate to dinitrogen via nitrite, nitric oxide and nitrous oxide. These results propose that the dissimilatory nitrite reductase of M.magnetotacticum may participate as $\mathrm{Fe}(\mathrm{II})$ oxidizing enzyme in magnetite synthesis under microaerobic conditions.
\end{abstract}

\section{Introduction}

Iron is an essential element for all living organisms. It participates in large number of biological processes. Magnetospirillum magnetotacticum synthesizes intracellular particles which are composed of ferrimagnetic iron oxide magnetite $\left\{\mathrm{Fe}_{2} \mathrm{O}_{3}\right.$ (FeO) $\}$ (Fig.1) and orients itself along the lines of earth's magnetic field by using the magnetosomes as magnetic sensors and consequently can find an optimal redox environment for growth[1,2]. Recently, the crystal structure and morphology of magnetites produced by the bacterium have been extensively studied by transmission electron microscopy, high resolution TEM and Mössbauer spectroscopy[3-5]. However, much less is known about the mechanism by which magnetite crystal is synthesized at room temperature. In the present study we have examined the enzymatic reduction and oxidation of iron and found that the $\mathrm{Fe}(\mathrm{III})$ reduction may be catalyzed by the cytoplasmic NADHFe(III) reductase and Fe(II) oxidation by the periplasmic dissimilatory nitrite reductase under microaerobic conditions.

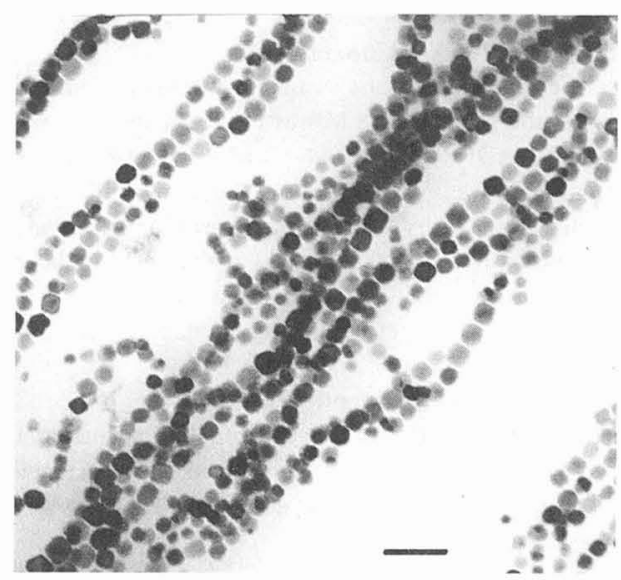

Fig.1 Electron micrograph of magnetosomes purified from M.magnetotacticum. Scale bar $=200 \mathrm{~nm}$. 


\section{Experimental}

\subsection{Preparation of periplasmic and cytoplasmic fractions from M.magnetotacticum}

M.magnetotacticum (ATCC31632) was cultivated in a chemically defined medium and harvested at the stationary phase. Periplasmic and cytoplasmic fractions were prepared by the method of Alefounder and Ferguson[6]. The periplasmic fraction was defined as those proteins released into the supernatants after treating the cells with EDTA plus lysozyme together and washing the spheroplasts with $0.5 \mathrm{M} \mathrm{NaSCN}$. The contamination of cytoplasmic proteins into the periplasmic fraction were judged by measuring the activity of malate dehydrogenase defined as cytoplasmic marker protein.

\subsection{Purification of NADH-Fe(III) oxidoreductase}

The cells suspended in $10 \mathrm{mM}$ Tris- $\mathrm{HCl}$ buffer $\mathrm{pH} 8.0$ were disrupted with a French press. Unbroken cells and magnetosomes were removed by centrifugation at $10000 \mathrm{x}$ for $15 \mathrm{~min}$ at $4^{\circ} \mathrm{C}$. The supernatant was furthermore centrifuged at $104000 \mathrm{x}$ for $1 \mathrm{~h}$. The supernatant obtained( soluble fraction) was used as starting materials for purification of NADH-Fe(II) oxidoreductase. The soluble fraction was fractionated with ammonium sulfate, and the precipitate that appeared between 45 and $65 \%$ saturation was dissolved in $0.1 \mathrm{M}$ Tris- $\mathrm{HCl}$ buffer pH8.0. The suspension was subjected to gel-filtration with a Sephacryl S-200 column. The resulting eluate was loaded on to a Butyl Toyopearl column. The enzyme adsorbed on the column was eluted by a decreasing concentration gradient of ammonium sulfate from $30 \%$ to $10 \%$ saturation. The eluate obtained was used as the purified NADH-Fe(III) oxidoreductase preparation of M.magnetotacticum.

\subsection{Purification of $\mathrm{Fe}(\mathrm{H})$-nitrite oxidoreductase}

The soluble fraction was prepared from the sonicated extract by centrifugation at $104000 \mathrm{~g}$ for $1 \mathrm{~h}$ and applied to a DEAEToyopearl column. The activity of Fe(II)-nitrite oxidoreductase was detected in the passed fraction. The desalted solution was applied to a CM-Toyopearl column and the enzyme was eluted with a linear gradient of $0-0.5 \mathrm{M} \mathrm{NaCl}$. The eluate concentrated with ammonium sulfate fractionation was subjected to gel filtration on a Sephacryl S-200 column. The fractions representing the activity were used as the purified enzyme.

\subsection{Enzyme assay}

The reaction mixture for NADH-Fe(III) oxidoreductase was assayed in $20 \mathrm{mM}$ sodium phosphate buffer pH 7.0 containing $0.1 \mathrm{mM}$ NADH, $1 \mu \mathrm{M}$ FMN, $1 \mathrm{mM}$ ferrozine, $0.2 \mathrm{mM}$ ferric citrate and enzyme in a total volume of $1.0 \mathrm{ml}$. The reaction was started by the injection of enzyme and the absorbance change at $562 \mathrm{~nm}$ was followed.

The Fe(II)-nitrite oxidoreductase activity was measured as follows[7]. The reaction mixture was assayed in $10 \mathrm{mM} \mathrm{Tris-} \mathrm{HCl}$ pH8.0 containing $0.1 \mathrm{M} \mathrm{D}$-glucose in a total volume of $3 \mathrm{ml}$. After a liquid paraffin was floated on a surface of the solution, Dglucose oxidase $(0.8$ unit/ml $)$ and catalase $(20$ units $/ \mathrm{ml})$ were added to the reaction mixture and incubated for $5 \mathrm{~min}$ at $20^{\circ} \mathrm{C}$. Then, $30 \mu \mathrm{l}$ of $60 \mu \mathrm{M}$ cytochrome $c d_{1}$ and $15 \mu \mathrm{l}$ of $100 \mathrm{mM} \mathrm{FeSO}_{4}$ were added to the reaction mixture and the reaction was started by the injection of $15 \mu \mathrm{l}$ of $20 \mathrm{mM} \mathrm{NaNO}_{2}$. In $1,3,5$ and $10 \mathrm{~min}$ after the injection of nitrite, $0.1 \mathrm{ml}$ of the reaction mixture was taken by gas-tight syringe and the Fe(II) and nitrite contents were determined by the method of Stookey[8] and Nicholas and Nason[9], respectively.

\section{Results and Discussion}

\subsection{NADH-Fe(III) oxidoreductase}

The purified enzyme consist of one polypeptide chain with the molecular mass of $36 \mathrm{kDa}$. The enzyme utilized NADH or NADPH in the presence of FMN as reductant and showed maximum activity at pH 7.0(Table 1). The apparent Km values for $\mathrm{NADH}$ and NADPH were about $4.3 \mu \mathrm{M}$ and $119 \mu \mathrm{M}$, respectively. The presence of flavin was necessary for iron reductase activity. FMN was preferred as an electron mediator over FAD. The activity of M.magnetotacticum iron reductase was specifically inhibited by $\mathrm{Zn}^{2+}$ to be a partial mixed-type inhibitor. The Ki value was about $19 \mu \mathrm{M}$ with respect to NADH. Some cytosolic iron reductases have been detected in the gram-negative bacteria including E.coli and P.aeruginosa[10]. These enzymes have been shown to utilize flavin as cofactors for the electron transfer to ferric iron and the activity was strongly inhibited by $\mathrm{Zn}^{2+}$. Therefore, the iron reductase of M.magnetotacticum may be closely related to these enzymes.

\subsection{Fe(II)-nitrite oxidoreductase}

Recently we have found that the dissimilatory nitrite reductase of M.magnetotacticum shows high Fe(II)-nitrite oxidoreductase activity|7l. The enzyme could be detected in the magnetite-containing cells but not in the non-magnetic cells. The enzyme showed absorption maxima at 643 and $409 \mathrm{~nm}$ in the oxidized form, and 663, 551, 522 and $418 \mathrm{~nm}$ in the reduced form 
and composed of two identical subunits with a molecular mass of $54 \mathrm{kDa}$, each containing a $c$ - and $d_{1}$-type heme. The activity was about $0.57 \mathrm{~mol}$ ferrous iron $/ \mathrm{mol}$ of enzyme/sec at $\mathrm{pH}$ 8.0. The oxidized ferrous iron/reduced nitrite ratio was about 1.4 , indicating that nitrite is reduced to NO(Fig.2).

On the other hand, M.magnetotacticum is a microaerobic denitrifier; the bacterium can synthesize a large amount of magnetite under microaerobic conditions in the presence of nitrate[11-13]. The bacterium scarcely synthesizes the magnetite in the absence of nitrate and further, the bacterium can not grow with nitrate respiration under the strictly anaerobic conditions. Recently, we have purified $c c b$ type cytochrome $c$ oxidase from M.magnetotacticum [14]. The enzyme is very similar to the respiratory terminal oxidases purified from microaerobic photosynthetic bacteria, Rhodobacter capsulatus[15] and Rhodobacter sphaeroides[16]. Further, it is synthesized constitutively in both nonmagnetic cells and magnetic cells. These results strongly propose that M.magnetotacticum does not respire with nitrate/nitrite but oxygen under microaerobic conditions.

\section{Conclusion}

M.magnetotacticum is a gram-negative bacterium and seems to uptake ferric iron chelated with quinate by the systems composed of an outer membrane receptor, a periplasmic protein and several inner membraneassociated proteins. In the present study we have found that neither of the membrane fraction nor periplasmic fraction prepared from the bacterium showed any $\mathrm{NAD}(\mathrm{P}) \mathrm{H}-\mathrm{Fe}(\mathrm{III})$ oxidoreductase activity, indicating that the reduction of iron occurs in cytoplasm. Furthermore, the enzymatic properties and molecular features of M.magnetotacticum iron reductase are very similar to those of iron reductases which have been detected in other bacteria. These results suggest that M.magnetotacticum iron reductase may be involved in both the transfer of iron to iron-requiring metabolic systems and the supply of ferrous iron for magnetite synthesis in cytoplasm .

On the other hand, Egusa et al.[17] have reported that nitrite can be used as an effective oxidizing reagent for the synthesis of spinel-type ferrites in aqueous solution. In the present study, we have found that $c d_{1}$ type nitrite reductase possesses novel $\mathrm{Fe}$ (II)-nitrite oxidoreductase activity. Mann et al.[18] have proposed that bacterial magnetite synthesis may involve processes similar to the formation and transport of ferrihydrite cores in the iron storage protein, ferritin. Therefore, M.magnentotacticum cytochrome $c d_{1}$ appear to participate in oxidation of ferrous iron with nitrite under the microaerobic conditions. It links to the ferritin which catalyzes the oxidation of ferrous iron with oxygen in the process of the ferrihydrite synthesis.

Cytochromes $c d_{1}$ of denitrifyifng bacteria are considered to be localized in the periplasmic space or loosely bound to cytoplasmic membrane[19]. In the present study, we have found that some of M.magnetotacticum cytochromes $\alpha_{1}{ }_{1}$ are identified on the cytoplasmic membranes. These results suggest that M.magnetotacticum cytochrome $c d_{1}$ is originally placed on the periplasmic face of the cytoplasmic membrane. However, the magnetosome vesicles are present in the cytoplasm and furthermore, the magnetosome membranes do not appear to be contiguous with the cytoplasmic membranes[20]. To elucidate the involvement of cytochrome $c d_{1}$ in magnetite synthesis in vivo, the origin of magnetosome membrane and the mechanism
Table 1 Effects of reaction components on ferric reductase activity

\begin{tabular}{cc}
\hline Reaction composition & $\begin{array}{l}\text { specific activity } \\
(\mu \mathrm{mol} F \mathrm{Fe}(1)-\text { ferrozine } \\
\left.\mathrm{min} \mathrm{mg}^{-1}\right)\end{array}$ \\
\hline Complete & $1.25(100 \%)$ \\
-FMN & $0.18(11 \%)$ \\
-FMN, +FAD & $0.28(18 \%)$ \\
-NADH, +NADPH & $0.26(16 \%)$ \\
-IErric iron & $0(0 \%)$ \\
\hline
\end{tabular}

Fig.2 Fe(II)-nitrite oxidoreductase activity of cytochrome $c d_{1}$ purified from M.magnetotacticum.

The rates of Fe(II) oxidations in the presence of enzyme( $)$ and in the absence of enzyme ( $O$ ). The rates of nitrite reductions in the presence of enzyme ( $\square$ ) and in the absence of enzyme( $\square$ ).

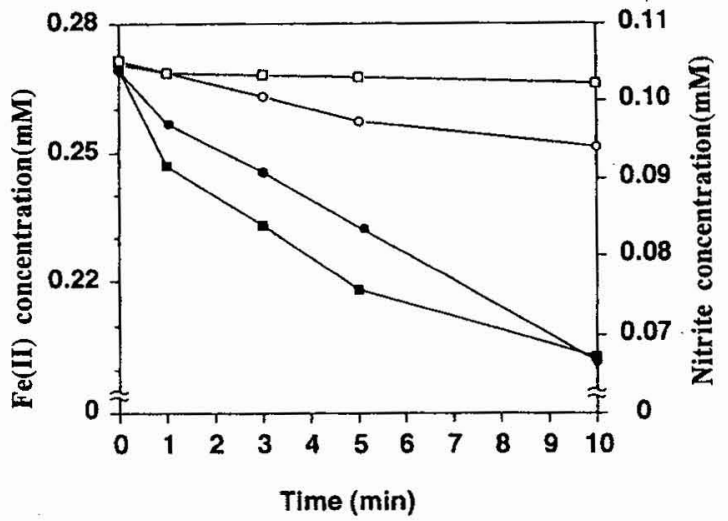

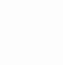


of iron uptake from cytoplasm into magnetosome vesicles should be studied in the future.

\section{Acknowledgments}

This work was supported by a Grant-in-Aid for Scientific Research to Y.Fukumori from the Ministry of Education, Science and Culture of Japan.

\section{References}

[1]Blakemore R.P., Annu.Rev.Microbiol. 3 6(1982) 217-238.

[2]Frankel R.B., Annu.Rev.Biophys.Bioeng. 13(1984) 85-103.

[3]Meldrum F.C., Mann S., Heywood B.R., Frankel R.B. and Bazylinski D.A., Proc.R.Soc.Lond.B 251(1993) $237-242$.

[4]Bazylinski D.A., Garratt-Reed A.J. and Frankel R.B., Microsc.Res.Tech. 2 7(1994) 389-401.

[5]Farina M., Kachar B., Lins U., Broderick R. and Lins de Barros H., J.Microsc. 173(1994) 1-8.

[6]Alefounder P.R. and Ferguson S.J., Biochem.J. 192(1980) 231-240.

[7]Yamazaki T., Oyanagi H., Fujiwara T. and Fukumori Y., Eur.J.Biochem. 233(1995) 665-671.

[8]Stookey L.L., Anal.Chem. 42(1970) 779-781.

[9|Nicholas D.J.D. and Nason A., Methods Enzymol. 3(1957) 981-984.

[10|Fontecave M., Coves J. and Pierre J.L., Biometals 7(1994) 3-8.

[11]Escalante-Semerena J.C., Blakemore R.P. and Wolfe R.S., Appl.Environ.Microbiol. 40(1980) 429-430.

[12]Baz.ylinski D.A. and Blakemore R.P., Appl.Environ.Microbiol. 4 6(1983) 1118-1124.

[13]Blakemore R.P., Short K.A., Bazylinski D.A., Rosenblatt C. and Frankel R.B., Geomicrobiol.J. 4(1985) 53-71.

[14]Tamegai H. and Fukumori Y., FEBS Lett. 347(1994) 22-26.

[15]Gray K.A., Grooms M., Myllykallio H., Moomaw C., Slaughter C. and Daldal F., Biochemistry 33(1994) 3120-3127.

[16]Garcia-Horsman J.A., Berry E., Shapleigh J.P. Alben J.O. and Gennis R.B., Biochemistry 33(1994) 3113-3119.

[17]Egusa K., Marugame K., Abe M. and Itoh T., "Demonstrations:Ferrite film synthesis from aqueous solution",Proc.6th International Conference on Ferrites (1992), Yamaguchi T. and Abe M. eds(The Japan Society of Powder Metallurgy), pp.11-14.

[18]Mann S., Sparks N.H.C. and Board R.G., Adv.Microb.Physiol. 3 1(1991) 125-181.

[19]Coyne M.S., Arunakumari A., Pankratz H.S. and Tiedje J.M., J.Bacteriol. 172(1990) 2558-2562.

[20]Gorby Y.A. Beveridge T.J. and Blakemore R.P., J.Bacteriol. 170 (1988) 834-841. 